\title{
The effect of regional original income and balance funding on regional government financial performance
}

\author{
Noor Farieda Awwaliyah, ${ }^{1}$ Ratno Agriyanto, ${ }^{2}$ \\ Dessy Noor Farida ${ }^{3}$
}

1,2,3Universitas Islam Negeri Walisongo Semarang, Indonesia email: ratnoagriyanto@walisongo.ac.id

\begin{abstract}
Purpose - The purpose of the research was to determine the effect of local revenue and intergovernmental revenue on the financial performance of local government.

Method - This research used Stewardship Theory. The method used is quantitative research method. The method of data analysis used is multiple linear regression analysis. This research used secondary data. The population in this research is the Regency in Central Java which consists of 29 regencies and 6 cities.

Result - The results showed that first, local revenue had positive effect on financial performance of local government. Second, intergovernmental revenue had positive effect on financial performance of local government. Third, local revenue and intergovernmental revenue together had influence on financial performance of local government.

Implication - The practical implication of this research is that the Regency Governments in Central Java are expected to reduce dependence on the central government by optimizing the potential of existing income sources to be able to further improve their financial performance.
\end{abstract}

Originality - An originality of research is focused on two variables; regional original income and intergovernmental revenue and uses the measurement of independence index for the dependent variable. financing.

Keywords: local revenue; intergovernmental revenue; financial performance of local government 


\section{Introduction}

Central Java Province is one of the provinces that has implemented regional autonomy on the basis of the Regional Autonomy Law No. 32 of JIAFR | 262004 concerning Regional Government. Regional autonomy is a manifestation of a shift in a centralized government system towards a decentralized system that aims to enable local governments to accelerate public welfare through improving services to the community and promoting regional independence so that it will create efficiency and effectiveness in the utilization of financial resources.

The era of Regional Autonomy as it is now, in realizing good governance, the governent is making efforts to increase transparency and accountability in the management of state finances (Pramono, 2014). Due to the existence of regional autonomy, the Regional Government shall conduct management and regional financial accountability stipulated in Government Regulation Article 4 No. 105 of 2000 which affirms that regional financial management must be carried out in an orderly, compliant, applicable, efficient, effective, transparent and responsible laws and regulations with regard to justice and compliance (Ebit Juliawati, 2012). Application of government accountability is in accordance with QS. An-Nisa verse 58 and QS. Al-Anfal verse 27.

The Central Government delegates authority to the Regional Government accompanied by the submission of funding responsibilities. Regional government funding is divided into two ways, namely utilizing regional potential (internal sources) and transfer funds from central-regional finance and between regions (external sources). Regional original income is the main source of regional income originating from the development of existing regional potential and used to improve services to the community. The greater Regional original income financial performance of the government because the level of regional independence is higher. Government activities are also funded by balancing funds, namely aid funds originating from the central government. Balancing funds are a real manifestation of decentralization from the center to the regions so that there are no gaps. The 
greater the balance fund shows that the financial performance of the local government is not good because the level of independence is low.

In fact, there are still many problems that occur in the Central Java Provincial Government in its financial management like the existence of regencies that have not achieved the 2017 ROI realization target, namely Kudus Regency, Rembang Regency, Pekalongan City and Tegal City. The financial independence of the regency government in Central Java in 2017 is still relatively low because local revenue is still very small compared to the total central/provincial government assistance to finance government activities. There is only one city that has independence above $50 \%$ that is Semarang City.

In 2017, even though Central Java Province has received an unqualified opinion, but there are still four regencies in Central Java Province that have a fair opinion with Exceptions, namely Brebes, Klaten, Rembang and Tegal City. Rembang Regency has never received an unqualified opinion because of the factor of recording assets that have not been settled (Nurfmrembang, 2017).

Based on the above findings, it is clear that the financial performance of the regional government can be considered not good. To assess the financial performance of regional governments is to conduct a ratio analysis of the Regional government budget that has been determined and approved. Research like this has been done by Gita Maiyora which shows that wealth ROI has no effect and intergovernmental revenue influences the financial performance of regency governments on Sumatra Island (Maiyora, 2015). Putu Riesty Masdiantini and Ni Made Adi Erawati's research show that prosperity ROI and intergovernmental revenue do not affect the financial performance of local governments (Erawati, 2016).

Based on the description above, it can be concluded that the measurement of financial performance of local government is very important because there are still many problems that occur in the regencies in Central Java. This performance measurement is expected to be used as an evaluation for local governments and can be used as public information to the public. 
This study aims to empirically examine the effect of Regional original income and Balancing Funds on the financial performance of Regency Governments in Central Java in the 2016-2017 fiscal year.

\section{JIAFR | 28 Literature Review}

\section{Stewardship Theory}

In relation to the public sector, the theory used in this research is a stewardship theory that explains the relationship between the principal and the steward. According to Lex Donaldson and James H. Davis, the theory of stewardship describes a situation in which management is not motivated by individual goals but rather is aimed at the interests of the organization (Davis, 1991).

Stewardship theory explains the relationship between principals namely people and stewards, namely the government. This relationship is created because of the human nature that can be trusted, responsible, have integrity and honesty on the other side. The government as a party that has more information, especially in the financial sector, is expected to be able to bring transparency to the people according to the expectations and beliefs that have been given by the people.

According to Raharjo (2007) stewardship theory has the roots of psychology and sociology which are designed to explain the situation where the manager is a steward and acts in the interests of the owner. This theory explains that managers will behave according to common interests. When the interests of the steward and the owner are not the same, the steward will try to work together rather than oppose it, because the steward feels the common interest and behaves according to the owner's behavior. It is a rational consideration because the steward looks more at the effort to achieve organizational goals.

The regional government is explained in this theory that the government as the executor of government will work and behave in accordance with the common interest, that is for the interests of the people. Stewardship theory 
assumes a strong relationship between organizational success and owner satisfaction. The government will make maximum efforts in running its government to achieve the government's goal of increasing people's welfare. If this goal is achieved by the government, the people as owners will be satisfied with the government's performance (Fauza, 2015).

\section{Local Government Financial Performance}

Performance is the achievement of what is planned, both by individuals and organizations. Simply put, the performance of a person or organization is said to be good if the results achieved are in accordance with the planned targets. If the achievement exceeds the target, then the performance is said to be very good, whereas if it is lower than the target it can be said that the performance is poor.

Financial performance is a measurement of performance using financial indicators. Regional financial performance or regional capacity is one of the measures used to see the ability of the region in carrying out regional autonomy (Halim, 2012). Based on the statement, it can be concluded that the financial performance of the regional government is an overview of the achievement of a program/policy that has been planned by the regional government for a certain period which can be measured using financial indicators.

Performance measurement is the process of continuous monitoring and reporting of achievement of activities, especially progress on planned objectives. Continuous performance measurement will provide feedback, so that continuous improvement efforts occur to achieve goals in the future.

Measurement of performance against institutions or organizations does not only apply to institutions or organizations that are profit oriented, but also needs to be done on institutions or non-commercial organizations. This is done in order to be able to know the extent to which the government carries out its duties in the running government in carrying out development and service to the community by submitting financial accountability reports. 
Performance measurement is considered very important to assess organizational accountability in producing better public services. Accountability is not just an ability that shows how public money is spent, but includes the ability to show that public money has been spent economically, efficiently and effectively (Mardiasmo, 2009).

The financial performance of the regional government is a form of accountability for the trust that has been given by the community to the local government that has been regulated by Allah in QS. An-Nisa verse 58 and QS. Al-Anfal verse 27. The government is obliged to account for the mandate that has been received to improve the welfare of its people.

QS. An-Nisa verse 58, which means: "Verily, Allah commands you to convey the message to the one who has the right to receive it and to judge between mankind so that you may be justified. Allah is the Best of you. Allah is the Hearer, the Seer".

The above paragraph explains that a mandate must be submitted to a person entitled to it. In this regard, the government is a party that is entrusted by the people and must carry out the mandate properly and fairly for the benefit of its people.

QS. Al-Anfal verse 27, which means: "O ye who believe! Betray not Allah and the Messenger, nor betray the trusts which ye entrust unto, as you know".

The above verse explains that someone who has been entrusted cannot betray. This is related to the government that has been entrusted by the people and has to run the government well without treating the people with the interests of the people more than personal interests.

\section{Balancing Fund}

Intergovernmental revenue is a number of funds transfered from the center that are deliberately made to finance local government programs. One of the objectives of providing such balance funds is to reduce fiscal disparity between the government and the regions and between regions so that there is no one region left behind and increase regional capacity in exploring regional economic potential. 
According to Law No. 33 of 2004, balancing funds are divided into three types, namely:

\section{Revenue Sharing (Taxes and Natural Resources)}

According to Law No. 33 of 2004, the revenue sharing fund is explained as funds originating from the State Budget allocated to the regions based on percentage figures to fund regional needs in the context of implementing decentralization. In its explanation, revenue sharing funds in the regional government budget are revenues derived from national resources in the region in the form of taxes and natural resources.

\section{General Allocation Fund (GAF)}

According to Law No. 33 of 2004 concerning financial balance between the central government and regional governments, it is said that the general allocation fund is funds originating from the state budget allocated with the aim of equitable distribution of financial capacity between regions to finance their expenditure needs in the framework of implementing decentralization.

\section{Special allocation funds (SAF)}

The definition of special allocation funds is regulated in Law No. 33 of 2004 concerning financial balance between central finance and regional finance, which states that special allocation funds, here in after referred to as specific allocation funds, are funds originating from Regional government budget revenues allocated to certain regions with the aim of helping fund special activities which are regional affairs and in accordance with national priority. Special allocation funds is prioritized to assist regions with financial capacity below the national average, in order to fund the activities of providing physical facilities and infrastructure for basic services that have become regional affairs. 


\section{Regional original income}

According to Law No. 33 of 2004, regional original income is a source of regional revenue that is extracted to be used as the local government's capital JIAFR | 32 in financing development and regional businesses to minimize dependence on funds from the central government. The ability of an area to explore Regional original income will affect the development and development of the area. Besides that, the greater the contribution of regional original income to the total regional expenditure budget, the better the government's performance will be.

Regional original income groups are divided into four types of income (Halim, 2012): 1) Regional Taxes; Based on Law No. 34 of 2004 concerning changes to Law No. 18 of 1997 concerning Regional Taxes and Regional Levies; it is stated that what is meant by regional tax is obligatory contributions made by individuals and entities to the regions without balanced direct benefits, which can be imposed based on applicable laws and regulations, which are used to finance the administration of regional government and regional development. 2) Regional Retribution; Based on Law No. 28 of 2009 concerning regional taxes and retributions, regional levies are regional levies as payments for services or special permits granted specifically and/or provided by the regional government for the benefit of individuals or entities. 3) Results of Separate Regional Wealth Management; The results of the management of separated regional wealth are regional revenues derived from the management of separated regional wealth. 4) Other Legitimate Regional original income; This income is the regional income that comes from others belonging to the regional government.

\section{Hypothesis Development}

\section{The Effect of Regional original income on Local Government Financial Performance}

Regional original income is income originating from levies carried out by the regions based on applicable regulations that can be imposed on any 
person or government-owned or private business entity because of the acquisition of services provided by the government (Ebit Juliawati, 2012). An increase in Regional original income will result in an increase in government financial performance, because the greater the Regional original income, the better the level of financial independence of local governments.

Cherry DhaWenny's research shows that Regional original income has an effect on the financial performance of local governments in South Sumatra Province. This means that the entire Regional original income component greatly influences the financial performance of the regency and city governments in South Sumatra Province in accordance with the principles of regional autonomy (Wenny, 2012). Based on the description, the first hypothesis in this study is:

$H_{1}$ : Regional original income has a positive effect on local government financial performance (financial independence)

\section{The Effect of Balancing Funds on Local Government Financial Performance}

The Intergovernmental Revenue is a number of funds transfers from the central government that are deliberately made to finance local government programs. The greater the balance fund shows that the level of independence of the local government is getting lower. Local governments still depend on the central government to finance all government activities.

Elychia Roly Putri's research shows that intergovernmental revenue has a negative effect on the financial performance of regional governments. This indicates that the greater the intergovernmental revenue, the lower the level of financial independence of local governments because they are still dependent on central government funds (Putri, 2014). Based on the description, the second hypothesis in this study is:

$\mathrm{H}_{2}$ : Balancing funds have a negative effect on local government financial performance (financial independence) 


\section{The Effect of Regional original income and Balancing Funds on Local Government Financial Performance}

Regional original income and balancing funds are sources of local JIAFR | 34 government revenue to finance all of their activities. Both of these funding sources are very important for running the government. Ebit Juliawati's research, et al. showed that ROI and balancing funds affected the financial performance of local governments (Ebit Juliawati, 2012).

In this study, to measure the financial performance of regional governments is to use an analysis of the regional independence ratio. Then Regional original income and balance funds have different effects, namely Regional original income has a positive effect and balance funds have a negative effect. Based on the description, the third hypothesis in this study is:

$H_{3:}$ Regional original income and balancing funds affect the local government financial performance (financial independence)

Based on the study of theory and the formulation of hypotheses, the research model is presented in figure 1 .

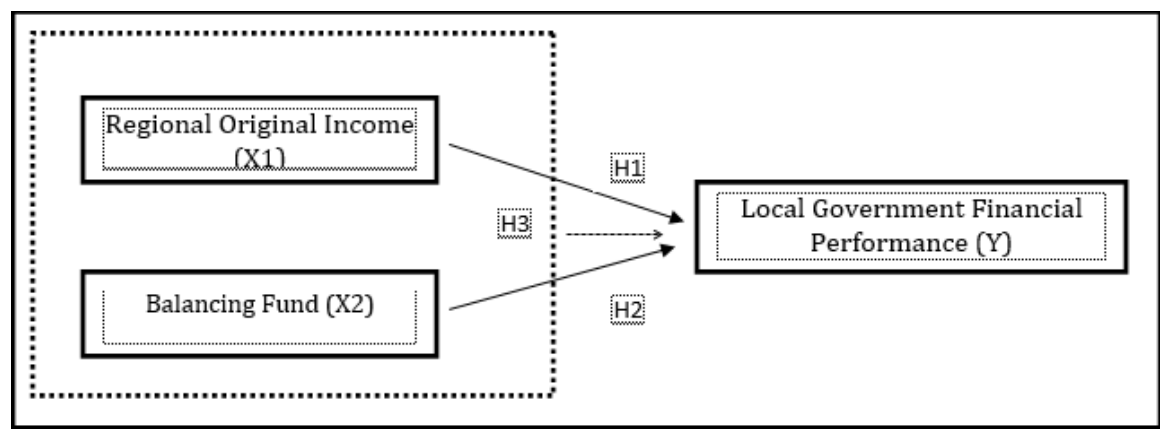

Figure 1. Research Model 


\section{Research Methods}

Judging from its nature, this research is classified as quantitative research (conclusive research design). The data used are secondary data obtained from the documentation of the Supreme Audit Agency Representative of Central Java Province. Data is processed with the help of SPSS 22.0 software for Windows.

This study is population-based research. Central Java Province consists of 29 regencies and 6 cities, so all regencies and cities are sampled in this study. Regencies/ Cities in Central Java Province include Banjarnegara Regency, Banyumas Regency, Batang Regency, Blora Regency, Boyolali Regency, Brebes Regency, Cilacap Regency, Demak Regency, Grobogan Regency, Jepara Regency, Karanganyar Regency, Kebumen Regency, Kendal Regency, Klaten Regency, Kudus Regency, Magelang Regency, Pati Regency, Pekalongan Regency, Pemalang Regency, Purbalingga Regency, Purworejo Regency, Rembang Regency, Semarang Regency, Sragen Regency, Sukoharjo Regency, Tegal Regency, Temanggung Regency, Wonogiri Regency, Wonosobo Regency, Magelang City, Pekalongan City, Salatiga City, Semarang City, Surakarta City, and Tegal City.

This study examines two independent variables, namely local revenue and balance funds. The Regional original income variable is measured by looking for its contribution to the Total Regional Revenue as follows (Putri, 2015):

$$
R O I=\frac{\text { Regional Revenue }}{\text { Total Regional Revenue }} \times 100 \%
$$

Meanwhile, the balance fund variable is measured by looking for its contribution to the Total Regional Revenue as follows (Putri, 2015):

$$
\text { Balance Fund }=\frac{\text { Balance Fund }}{\text { Total Regional Revenue }} \times 100 \%
$$


In this study, Local Government Financial Performance is the dependent variable. Measurement of variables uses the independence ratio with the following formula (Faud, 2016):

To assess the level of independence of the local government, it can refer to Kepmendagri No. 690,900,327 in 1996, as in Table 1 below:

The financial independence ratio illustrates the level of regional dependence on external funding sources. The higher the independence ratio means the level of regional dependence on assistance from the central government is getting lower, and vice versa.

In this study, the regional financial performance used as research data is the regional financial independence in the following year $(\mathrm{Yn}+1)$. This is because the concept in this study is to see how the influence of ROI and Balancing Funds in a given year (Xn) will affect financial independence in the following year $(\mathrm{Y} n+1)$, so that the data used to measure regional financial independence is 2016-2017. The research data was analyzed by multiple linear regression analysis.

Table 1. Level of Regional Independence and Financial Capability

\begin{tabular}{cc}
\hline Financial ability & $\begin{array}{c}\text { Level of independence } \\
\text { (\%) }\end{array}$ \\
\hline Very low & $0 \%-25 \%$ \\
Low & $25 \%-50 \%$ \\
Medium & $50 \%-75 \%$ \\
Hight & $75 \%-100 \%$ \\
\hline
\end{tabular}

Source: Kepmendagri No. 690.900.327/1996 
The effect of regional original income and balance funding on ...

\section{Results and Discussion}

The results of the calculation of local government financial performance (Regional Independence Ratio) show that the average independence of the regencies in Central Java Province for the period 2016-2017 is 23.29\% with a standard deviation value of $11.62 \%$. The average level of independence of JIAFR | 37 Central Java is $23.29 \%$, which is included in the very low criteria of financial independence. This shows that the regency/city governments in Central Java are still very dependent on assistance from the center or the regions and have not been able to explore ROI sources optimally.

The region that has the highest value or highest financial independence is Semarang City at $82.47 \%$ in 2017 . This shows that Semarang City as the Capital City of Central Java Province has a high level of independence in carrying out its government activities. While the regions that have the lowest value or have the lowest financial independence are Blora is $11.28 \%$ in 2017.

The average Central Java Regional Revenue during the 2015-2016 period was $15.98 \%$ with a standard deviation value of $5.71 \%$. The standard deviation value is smaller than the average value. This means that the data distribution is good and even. The region with the highest value or the highest ROI is Semarang City at $36.35 \%$ in 2016 . This is due to the very strategic position of Semarang City, as the provincial capital, government center, trade center and other services and facilities that make a significant contribution in building the economy of the city of Semarang. While the region that have the lowest value or have the lowest ROI is Klaten at $8.75 \%$ in 2015. This is due to Klaten, a source of income from taxes, levies, income from separated regional wealth management and other legitimate ROI, is still low on low-income or low-ability region to explore ROI.

The average Central Java Balancing Fund during the period 2015-2016 was $61.90 \%$ with a standard deviation value of $7.55 \%$. The standard deviation value is smaller than the average value. This means that the data distribution is good and even. The region that has the highest value or has the highest balancing fund is Salatiga City at $84.30 \%$ in 2016. This shows that 
Salatiga City is an area that has a high dependence on funding from the central government. While the regions that have the lowest value or have the lowest balancing fund are Semarang City at 37.95\% in 2015. This shows that Semarang City is a region that does not depend much on funding from the central government.

\section{Model Feasibility Test (Classical Assumption Test)}

The regression model will be declared good and can be done if it meets the classic assumption test, namely normality test, multicollinearity test, autocorrelation test and heterosociality test. And this research has fulfilled the classic assumption test, as shown in the table below:

\section{Multiple Linear Regression Test}

The multiple linear regression test was conducted to determine the effect of the independent variable, namely the ROI of the balance funds on the dependent variable, namely the financial performance of the local government (independence ratio).

Table 2. Summary of Classical Assumption Tests for Hypothesis Testing Effect of Regional original income (ROI) and Balancing Funds on Financial Performance in Local Governments

\begin{tabular}{lcc}
\hline Multicollinearity Test & Tolerance & VIF \\
\hline Regional original income & 1,000 & 1,000 \\
Balancing Fund & 1,000 & 1,000 \\
Heteroscedasticity Test (Glejser test) & Sig. t-test & \\
Regional original income & 0,745 & \\
Balancing Fund & 0,079 & \\
Durbin-Watson test & 2,008 & \\
Normality Test & & \\
Kolmogorov- Smirnov test & 0,200 & \\
Adj R Square & 0,762 & \\
$\mathrm{~N}=68$ & & \\
\hline
\end{tabular}


Table 3. Multiple Linear Regression Test Results

\begin{tabular}{|c|c|c|c|c|c|c|}
\hline & \multirow[b]{2}{*}{ Model } & \multicolumn{2}{|c|}{$\begin{array}{l}\text { Unstandardized } \\
\text { Coefficients }\end{array}$} & $\begin{array}{l}\text { Standardized } \\
\text { Coefficients }\end{array}$ & \multirow[b]{2}{*}{$T$} & \multirow[b]{2}{*}{ Sig. } \\
\hline & & B & Std. Error & Beta & & \\
\hline \multirow[t]{3}{*}{1} & (Constant) & $-2,283$ & ,734 & & $-3,109$ & ,003 \\
\hline & ROI & 946 & ,067 & ,848 & 14,208 & ,000 \\
\hline & Balancing Fund & ,669 & 172 & ,232 & 3,891 & ,000 \\
\hline
\end{tabular}

Based on table 3, the regression equation formed is:

$G F P=-2,283+0,946 R O I+0,669 B F$

Based on the regression equation above, it can be explained as follows:

Constant value of $-2,283$ means that if the ROI variable and balancing fund $(\mathrm{BF})$ are zero $(0)$, then the regional government financial performance (GFP) is equal to $-2,283$. But why predict regional government financial performance if ROI and balance funds are not yet available, because there are no sources of funds to run government activities. Negative constants can be ignored as long as the regression model meets the classical assumption test for multiple regressions. Negative constants generally occur if there is a considerable range between $\mathrm{X}$ (independent variable) and $\mathrm{Y}$ (response variable) (Mendenhall, 2011). In this study, X1 has a value range of $8.75 \%$ $36.35 \%$, X2 has a value range of $37.95 \%-84.30 \%$ while $\mathrm{Y}$ has a range of values of $11.28 \%-82.47 \%$.

The regression coefficient on the ROI variable of 0.946 is positive. This means that if there is an increase in ROI of $1 \%$, then the regional government financial performance (GFP) will increase by 0.946 where other factors are considered constant.

The regression coefficient on the Balancing Fund (BF) variable of 0.669 is positive. This means that if there is an increase in the Balancing Fund (BF) of $1 \%$, then the regional government financial performance (GFP) will increase by 0.669 where other factors are considered constant. 


\section{The Effect of Regional original income on Local Government Financial Performance}

Based on the testing of the influence of ROI on local government financial JIAFR | 40 performance, ROI has a significant positive effect $(0.946)$ of $0,000<0.05$ (below 5\%). Therefore, the first hypothesis is accepted.

The results of this study are in accordance with the theory and consistent with the research by Ebit Juliawati, Darwanis, Jalaluddin (2012) which states that ROI has a positive effect on the financial performance of regional governments. An increase in ROI will result in an increase in the government's financial performance. This can happen because the regency/city governments in Aceh Province emphasize the proceeds from their ROI which come from various sources managed by the region in the form of receipts of taxes, levies and other legitimate receipts stipulated in the Law.

Research conducted by Riswanda Imawan and Agus Wahyudin (2014) also shows the same results. The results showed that the wealth variable (ROI) had a positive influence on the financial independence of the Central Java region. Prosperity is closely related to the economic activities that run in the area. A high GRDP indicates that regional economic activities are stretching well, so that the amount of revenue from local revenues will be higher. The large number of production factors that emerge will bring regional revenue in the form of taxes and levies which become income for the regional treasury. High regional original income will cause the level of financial independence of the area to be better.

Regional autonomy funded by regional income and sourced from ROI is a more important concern compared to other sources of income, because ROI is income originating from the original management of the area itself. One of them is tax. ROI regarding tax is explained in QS. Al-Hujurat verse 15. If a country experiences a shortage of funds to finance its expenditure, the state has the right to collect taxes. In this case, the local government can tax the public to finance the running of government. The greater the regional income, 
the more independent an area is in carrying out regional autonomy. Local governments can use ROI as a means to improve regional development and improve the welfare of the surrounding community.

$\mathrm{ROI}$ is the original source of income from the management of the region itself, the greater the local revenue, the more independent an area is in carrying out regional autonomy. To increase ROI in realizing regional independence, the local government can optimize ROI by implementing several methods, including the implementation of intensification and extensification policies. The intensification strategy is a strategy used to increase existing regional income sources, while the extensification strategy is a strategy used to explore the potential of new regions during the law limits.

\section{The Effect of Balancing Funds on Local Government Financial Performance}

Based on the testing of the effect of balancing funds on the financial performance of regional governments, it has a significant positive effect $(0.669)$ of $0,000<0.05$ (below $5 \%$ ). Therefore, the second hypothesis is rejected because it is in the opposite direction.

This finding is not in accordance with the theory, but is consistent with the results of the study by Asmaul Azis (2016) which states that intergovernmental revenue has a positive effect on the financial performance of regional governments in East Java. The higher intergovernmental revenue, the better the financial performance of the local government, which is the transfer of central government funds to local governments. The magnitude of intergovernmental revenue shows that the availability of funds that can be used to finance government administration and services provided to the community can be better.

The results of this study are also in line with the results of research conducted by Gita Maiyora (2015). This study states that intergovernmental revenue has a positive effect on the financial performance of regencies/cities throughout Sumatra. The level of dependence of the regional government on the central government which is proxied by the BF portion in the total realization of regional revenues in accordance with the hypothesis is that it 
has a significant positive effect. This indicates that the higher the $\mathrm{BF}$ for the central government, the higher the level of government financial performance. This means that the intergovernmental revenue is one of the factors that must be considered to improve financial performance.

In addition to ROI, the main source of revenue for regional governments comes from balancing funds, that is the transfer of funds from the central government to local governments to assist in financing government activities. The aim of the balancing fund is to reduce the disparity between the central government and local governments by implementing fair distribution of funds. Central government justice is explained in QS. Al-Zukhruf verse 32. Balancing funds originate from the central government and are distributed to local governments as a form of central government justice to reduce intergovernment disparities. With the existence of a balance fund to help the regional government to finance the running of the government.

This shows that balancing funds have a positive influence on the financial performance of local governments, the higher the balance fund, the better the financial performance of the local government. Regency/city governments throughout Central Java are still very dependent on balancing funds. This is evidenced by the sample which overall the percentage of balancing funds is greater than $50 \%$ of the total regional income. Government activities means is run by most balance funds. The greater the balance fund, the better the performance of the local government, because local governments can use it well to run the government.

\section{The Effects of Regional original income and Balancing Funds on Local Government Financial Performance}

Based on the testing of the effect of ROI and balancing funds on the financial performance of regional governments jointly influential with a significance value of $0,000<0.05$ (below $5 \%$ ).

Regional original income and balancing funds greatly influence the financial performance of regional governments because both are the largest funding sources in government activities. Large Regional original income 
(ROI) indicates that local governments can maximize the income source of their owned regions. While large balancing funds can improve the financial performance of regional governments provided that the balance funds can be used optimally and wisely for governance activities in accordance with the principles of regional autonomy.

\section{Conclusion}

This study aims to examine the effect of local revenue (ROI) and balance funds on the financial performance of local governments. By using a population of all regencies/cities in Central Java, that are 29 regencies and 6 cities during the two years of observation (2016-2017), the researchers produced findings that: first, regional original income (ROI) significantly influence the financial performance of local governments; second, balance funds have a significant positive effect on the financial performance of local governments; third, regional original revenue (ROI) and balance funds jointly have a significant effect on the financial performance of regional governments.

The practical implication of this study is that the regency/city government in Central Java Province can reduce dependence on the central government by optimizing the potential of existing income sources to be able to further improve their financial performance. Because based on the results of research, the local government is only $23,29 \%$ which is very low category.

The researcher has several limitations. First, this study only uses one indicator to assess the financial performance of local governments, namely the independence ratio. Therefore, further researchers are advised to use other measurement indicators. Second, this study only uses two independent variables, namely Regional original income (ROI) and balance funds. Therefore, further researchers are advised to be able to use other variables that affect the financial performance of local governments in addition to those tested in this study. Third, this research is only limited to the regencies/cities of Central Java Province in 2016-2017. Therefore, the next researcher is 
advised to add a longer time span so that it will describe the actual conditions that occur.

\section{References}

JIAFR | 44 Davis, L. D. (1991). Stewardship Theory or Agency Theory: CEO Governance and Shareholder Return. Australian Journal of Management, 16(1), 4964.

Ebit Juliawati, D. J. (2012). Pengaruh Pendapatan Asli Daerah (PAD) dan Dana Perimbangan Terhadap Kinerja Keuangan Pemerintah Kabupaten/Kota di Provinsi Aceh. Jurnal Akuntansi Pascasarjana Universitas Syiah Kuala, 1(1), 15.

Erawati, P. R. (2016). Pengaruh Ukuran Pemerintah, Kemakmuran, Intergovernmental Revenue, Temuan dan Opini Audit BPK pada Kinerja Keuangan. E-Jurnal Akuntansi Universitas Udayana, 176-177.

Faud, R. (2016). Analisis Laporan Keuangan Pemerintah Daerah Cet.1. Bogor: Penerbit Ghalia Indonesia.

Fauza, N. (2015). Analisis Faktor-faktor yang Mempengaruhi Kelemahan Pengendalian Intern Pemerintah Daerah (Studi Empiri pada Pemerintah Daerah se-Sumatera).Jom FEKON, 1(2), 5.

Halim, A. (2012). Akuntansi Sektor Publik: Akuntansi Keuangan Daerah. Jakarta: Salemba Empat.

Kepmendagri No. 690.900.327. (1996).

Maiyora, G. (2015). Pengaruh Karakteristik Pemerintah Daerah Terhadap Kinerja Keuangan Pemerintah Daerah Kabupaten/Kota (Studi Empiris Kabupaten/Kota di Pulau Sumatera). Jom FEKON, 2(2), 13-14.

Mardiasmo. (2009). Akuntansi Sektor Publik. Yogyakarta: Andi Offset.

Mendenhall, W. (2011). A Second Course in Statistics: Regression Analysis [7th (Seventh) Edition. Prentice Hall.

Nurfmrembang. (2017). Tak Hanya Adiupra, Tahun 2018 Rembang Juga Incar WTP. https://www.nurfmrembang.com/berita/tak-hanya-adipuratahun-2018-rembang.

Pramono, J. (2014). Analisis Rasio Keuangan Untuk Menilai Kinerja Keuangan Pemerintah Daerah (Studi Kasus pada Pemerintah Kota Surakarta). Jurnal STIE AMA Salatiga, 7(13) , 85. 
Putri, E. R. (2014). Pengaruh Karakteristik Pemerintah Daerah Terhadap Kinerja Keuangan Pemerintah Daerah (Studi pada Pemerintah Provinsi di Indonesia Tahun 2008-2012). Skripsi Universitas Lampung, 48.

Raharjo, E. (2007). Teori Agency dan Teori Stewardship Dalam Perspektif Akuntansi. Fokus Ekonomi, 2(1), 39-40.

Republik Indonesia. (2004). Undang-Undang No. 32 tahun 2004 tentang Pemerintah Daerah.

Republik Indonesia. (2004). Undang-Undang No. 33 Tahun 2004 tentang Perimbangan Keuangan Antara Pemerintah Pusat dan Pemerintah Daerah.

Wenny, C. D. (2012). Analisis Pengaruh Pendapatan Asli Daerah (PAD) Terhadap Kinerja Keuangan Pemerintah Kabupaten dan Kota di Provinsi Sumatera Selatan. Jurnal Ilmiah STIE MDP, 2(1), 49. 
JIAFR | 46 